\title{
A Chronology of Charles Olson's Life and Correspondence
}

1910 Born 27 December in Worcester, Massachusetts; son of Charles (formerly Karl) Joseph Olson, who was brought as an infant from Sweden, and Mary Theresa Olson (née Hines), daughter of immigrants from southern Ireland. He was raised as an only child in a "three decker" tenement in Worcester. From 1915 the family spent summers in the seaside fishing town of Gloucester, Massachusetts. Very few of Olson's letters to his parents are known; see letter 2, to Homer and Viola Barrett.

1917-1928 Attended Abbott Street Grammar School and Classical High School in Worcester, graduating president of his class. He then took a ten-week trip to Europe as a result of a national oratorical contest. See letter 62 , to the school, and letter 159, to teacher Anna Shaughnessy.

1928-1932 Attended Wesleyan University, Middletown, Connecticut, majoring in English. For Olson's intellectual and extracurricular interests, see letter to the Rhodes Scholarship Committee. He met Barbara Denny during the Christmas holiday of his freshman year. His sole existing letter to her was copied into a notebook; see letter 5 .

Summer 1931 Spent this summer-and the subsequent three summers-as a substitute letter carrier in Gloucester. This is the subject of letter 1 , to his father. 
1932-1933 Spent M.A. year at Wesleyan under the direction of Wilbert Snow, professor of English. Almost forty Olson letters to Snow, spanning a lifetime, are archived at the Wesleyan library; see letters 3 and 168. Olson's M.A. thesis, "The Growth of Herman Melville," acknowledged help from an interview with Carl Van Doren. Several subsequent letters thank Van Doren for continued support; see letter 9.

1933-1934 Supported by research funds from Wesleyan, contacted Melville's granddaughters, Mrs. A. D. Osborne, of East Orange, New Jersey, who supplied crucial Melville volumes, and Eleanor Melville Metcalf, of Cambridge, Massachusetts. Many letters from Mrs. Metcalf exist at Storrs, but, except for occasional carbon copies (see letter 25), Olson's letters have not been located. During spring 1934 Olson roomed in Cambridge with ex-Wesleyan John Finch. Olson's letters to Finch have not been preserved, except for letter 4 .

1934-1936 Taught English at Clark University, Worcester; see letter 6, to Anne Bosshard, which also mentions the memorable three weeks Olson spent as a member of a swordfishing crew out of Gloucester.

August 1936 Met Edward Dahlberg in Gloucester; see letters 27 and 33. Both sides of the emotional and confrontational Olson-Dahlberg correspondence from 1936 through 1955 have been published in In Love, In Sorrow.

September 1936 Entered Harvard University as a graduate student in the English department; hired as a teaching assistant to William Ellery Sedgwick. No letters to Sedgwick are known to exist at present.

December 1936 Visited New York City and met Alfred Stieglitz (see letter 14) and Waldo Frank (see letter 10). Sixteen letters to Frank are housed at the University of Pennsylvania library.

Summer 1937 Finished paper on Melville and Shakespeare for F. O. Matthiessen. Through a smattering of letters, the 


\section{Chronology : $x x i x$}

teacher and his student kept in touch until Matthiessen's death in 1950; see letter 8.

September 1937 Returned to Harvard as a graduate student in the new American Civilization Program and a tutor in John Winthrop House. Olson took the famous "Westward Movement" course from Frederick Merk, professor of history. Carbon copies of three letters to Merk exist at Storrs; see letter 67 .

November 1937 Met in Cambridge with Dorothy Norman, who was preparing the first issue of Twice A Year, in which Olson's essay "Lear and Moby Dick" appeared. Yale has many Olson letters to Norman up to 1946; see letter 7 .

September 1938 Started final year at Harvard. Olson was awarded a Guggenheim Fellowship with the backing of Van Wyck Brooks (see letter 9); he spent it in Gloucester, working on a major book on Melville that he later discarded.

May 1940 Met two people of future importance to him: the artist Corrado Cagli (letters are unavailable at present) and his wife-to-be Constance Wilcock; see letter 11.

November 1940 Moved to New York City to look for work. Met Melville scholar Merton Sealts; see letter 57. The correspondence between Olson and Sealts was published and discussed by Sealts in his Pursuing Melville, $1940-1980$.

1941-1942 Worked in New York for the American Civil Liberties Union and, subsequently, the Common Council for American Unity; see letter 13, to the Office of Strategic Services, for details.

1942-1944 Worked for the Foreign Language Division, Office of War Information, Washington, D.C. Here he met, among others, Ruth Benedict (one letter is in the Vassar archive; see letter 22) and Adam Kulikowski (some copies of letters survive; see letter 21). Olson collaborated with Ben Shahn on a pamphlet, Spanish Speaking Americans in the War (Office of the 
Coordinator of Inter-American Affairs, 1943), and became a close friend; see letter 39, selected from the eleven letters to Shahn in the Archives of American Art.

July- Worked as an employee of the Democratic National December 1944 Committee, first at the national convention in Chicago, then on the "Everybody for Roosevelt" election rally in Madison Square Garden, then at the party's winter headquarters in Key West, Florida. For Olson's work on party matters, see letter 19, to Senator Hannegan.

January 1945 Decided on a career as a writer; wrote the poem "The K" celebrating that decision. In April 1945, Olson moved from Florida to a permanent base: 217 Randolph Place N.E., Washington, D.C.

August 1945 Finished Call Me Ishmael. "First Fact" was written during a visit to New Bedford and Nantucket. See letter 17, to William H. Tripp, curator of the Old Dartmouth Whaling Museum.

January 1946 Through publisher James Laughlin, made the first of twenty-two visits over the next two years to Ezra Pound at St. Elizabeths; see letter 18, to Winfred Overholser and Mary Rudge. Olson had worried about Pound's arrival (see letter 15, to Malcolm Cowley) and had written his piece on Pound, "This Is Yeats Speaking," which was published in Partisan Review (winter 1946). Pound expanded Olson's contacts, including short-term connections such as John Berryman (see letter 23) and Douglas Fox (see letter 26), and long-term friends such as Caresse Crosby (see letter 36) and Laughlin himself (see letter 164). See also letter 20, to Pound.

March- Visited New York, with Connie, as a lobbyist for April 1946 Polish interests; see letter 16, to Oscar Lange. Signed a contract with Reynal and Hitchcock for Call Me Ishmael (officially published 17 March 1947), and formed a lasting friendship with Monroe Engel, editor for that book and the later unfinished "Red, 


\section{Chronology : $x x x i$}

White, and Black"; see letter 28, one of the many letters to Engel at Harvard.

June 1946 Began correspondence with Jay Leyda on Leyda's Melville Log; see letter 44, one of twenty-five Olson letters in the Leyda archive at UCLA.

June 1947 Visited Gloucester. A lunch with Alfred Mansfield Brooks, the local historian, is taken to mark the beginning of the Maximus poems (letter 94).

July- Invited to the Northwest Writers' Conference in September Seattle. Olson, with Connie, shared a ride to the West 1947 Coast via Yellowstone Park. They then went to San Francisco, meeting Muriel Rukeyser (one letter is known; see letter 29), Kenneth Rexroth (no letters are known to exist at present), and Robert Duncan (over fifty letters are at Buffalo; see letters 68 and 149). Olson then traveled to Hollywood, meeting Robert Payne, who later visited Olson at Black Mountain; he published "The Kingfishers" in Montevallo Review (summer 1950). Letters to Payne are available mainly at Stony Brook; see letter 36.

October 1947- Stayed on to research Gold Rush manuscripts at January 1948 Berkeley and Sacramento. Olson's edition of The Sutter-Marshall Lease was published in 1948 by the Book Club of California. From California, Olson submitted a proposal to the Guggenheim Foundation for a project on the American West; see letter 28, to the Guggenheim Foundation, and letter 30, to Monroe Engel. During this period, Olson wrote his first letter to Frances Boldereff (29 December 1947) in reply to her inquiry; see letters 46 and 162 . Both sides of this emotional and intellectually productive correspondence are at Storrs and are now published.

February 1948 Returned to Washington, D.C., by train, and made two visits to Pound before their final break-up; see letter 31 .

May 1948 Received proofs of $y \& x$, a volume of Olson's poems and drawings by Cagli, from Caresse Crosby's Black Sun Press; the official publication date was 1 February 1949. 
July 1948 Stayed in Philadelphia for the Democratic Party's national convention, which was Olson's last fling in politics. At the Art Gallery he was impressed by the work of Sienese painter Giovanni di Paolo, as described in letter 33, to Edward Dahlberg and Caresse Crosby.

October 1948 Received help from Henry Murray toward a doctor's fee for treating Connie following a miscarriage. Nineteen letters to Murray dated from 1946 through 1953 are deposited at Storrs; most address Murray's psychological approach to Melville. See letters 34 and 55. Olson's first appointment as a visiting lecturer at Black Mountain College (BMC), 12-16 October. This was followed by seven more monthly visits during the academic year; see letter 35, to Josef Albers.

March- Worked intensively on "The Kingfishers" and "The

May 1949 Praises." Glimpses of this effort appear in letter 36, to Crosby and Robert Payne, and letter 37, to Kitue Kitasono.

June 1949 Met Vincent Ferrini, on a visit to Gloucester; see letter 42, to Ferrini.

July- Taught a summer session course at BMC titled "Verse August 1949 and Theatre." Olson wanted Michael Lekakis to orate in the original Greek as part of a summer production, but this plan failed; see letter 40, from the eleven in the Archives of American Art.

October 1949 Was the best man at the wedding of his friend Jean Riboud. See letter 39, to Shahn; no letters to Riboud known at present.

April- Wrote first letters to Robert Creeley, which helped

May 1950 with the revision of the "Projective Verse" essay; see letter 43. The exchange of letters-Olson's are now deposited at Stanford University—is being published in multiple volumes by Black Sparrow Press.

October 1950 Began correspondence with Cid Corman, which led to Olson's being "featured" in the first issue of Corman's Origin (April 1951) and several others; see letter 48. Olson's many letters at Texas have been 


\section{Chronology : xxxiii}

joined with Corman's at Storrs in Charles Olson and Cid Corman: Complete Correspondence 1950-1964.

January 1951 Departed for Mexico. The death of Olson's mother on Christmas Day 1950 delayed the trip by several weeks; see letter 49, to Rainer Gerhardt.

February- Contacted a number of experts about glyphs and sites July 1951 while in Mexico, including Tulane University's Robert Wauchope; see letter 50. Olson kept track of his Washington house through Frank Moore (letter 56 is from about half a dozen in possession of the recipient), and he kept in touch with Black Mountain College mainly through Fielding Dawson (letter 51 is from the archive of over twenty letters at Stony Brook). From Olson's correspondence during his five months in Lerma, Campeche, Creeley selected a number that were published as Mayan Letters.

July 1951 Returned to BMC. He contacted Shahn, resident artist at the college, and through him approached a foundation about funding the college's future; see letter 53, to Shahn and W. H. Ferry.

August 1951 Composed Letter for Melville 1951, which was printed at Black Mountain and sent to a meeting of Melville scholars in Pittsfield on Labor Day. Henry Murray's talk on that occasion produced a strong reaction from Olson; see letter 55, to Murray.

October 1951 Daughter Kate born on 23 October; see letter 55, to Murray, letter 133, to Constance Bunker, and letter 161, to Kate Olson.

May 1952 Began plans for the Institute of the New Sciences of Man by inviting Carl Sauer to lead it; see letter 47. Nine Olson letters to Sauer, now at Berkeley, were published in New World Journal (spring 1979).

October- On leave of absence from BMC, at the Washington November 1952 house; Connie stayed at Black Mountain in a trial separation. Olson wrote almost daily; see letter 59.

December Invited Carl Jung to the Institute of the New Sciences 1952- of Man; Marie-Louise von Franz came; see letter 60. March 1953 Christopher Hawkes and Edgar Anderson were 
invited, but could not come; see letter 61 . In the midst of the institute lectures, In Cold Hell, In Thicket arrived from Mallorca, published there by Creeley to Olson's complete satisfaction.

April 1953 Vincent Ferrini's magazine Four Winds, nos. 2/3, published "Maximus Letter 3 " and set Olson off on a flurry of activity on the Maximus series. The manuscript for Maximus 1-10 was completed and sent to Jonathan Williams in Stuttgart, Germany; it was published there in November 1953. See letter 63 to Williams, from about one hundred letters deposited at Buffalo.

June 1953 Began correspondence with the British Melville scholar Ronald Mason, an exchange that continued through the end of the year. Ten substantial letters are archived at Storrs; see letter 66.

September 1953 Began correspondence with Canadian poet Irving Layton, who was invited to BMC but whose visit was prevented by U.S. immigration laws. Olson was to have been invited to Canada (see letter 69, from the nine at Concordia; these were printed in Line in 1989). He did not have that opportunity until April 1960. See letter 74, to Raymond Souster, selected from fifteen letters at Lakehead. See also letter 91, to Kenneth McRobbie.

March 1954 Evicted from his Washington, D.C., house. He was appointed rector of Black Mountain College; Creeley arrived to teach. Great efforts were made to keep the college viable; for example, Olson sought approval from the U.S. government to enroll Korean veterans under the G.I. Bill; see letter 70, to the Department of Public Instruction, letter 71, to Gerald van de Wiele, and letter 72, to William Carlos Williams.

September 1954 Traveled to Boston to read at the Charles Street Meeting House. John Wieners was there, and he later came to BMC; see letter 86 . The next day Olson gave a reading in Gloucester; see letter 73, to Ferrini. Olson 
had with him copies of Maximus Poems 1-10 and the first two issues of the Black Mountain Review.

May 1955 Charles Peter Olson born on 12 May to Betty Kaiser, a student at BMC.

July- Continued as rector for BMC's last quarter; see letter

September 1956 76, to Edward Marshall. Maximus Poems 11-22 arrived from the publisher.

January 1957 Wrote “The Librarian." Olson kept in touch on the subject of dreams with former BMC student Michael Rumaker; see letter 79, from over twenty deposited at Storrs.

February- Traveled by train with Betty and Charles Peter to San March 1957 Francisco; here he gave a lecture titled "Special View of History" and read at the Poetry Center. Returned via Albuquerque, to visit Creeley. See letter 77, to Ruth Witt-Diamant.

August 1957 Finished closing down BMC, then moved with his family to 28 Fort Square in Gloucester. Olson began afresh on new Maximus poems; see letter 80, to Ferrini, letter 81, to Betty Olson, and letter 99, to Wesley Huss.

November 1957 Met Robin Blaser in Cambridge; see letter 78, from about twenty-five letters in Blaser's possession.

February 1958 Call Me Ishmael reissued by Grove Press through the agency of Donald Allen, who printed "The Lordly and Isolate Satyrs" in Evergreen Review and many of Olson's later works; see letter 90, from about 130 letters to Allen deposited at Storrs.

March 1959 Met Allen Ginsberg and Gregory Corso at their reading in Boston; see letter 83. The ten letters to Ginsberg at Columbia span the years 1957 to 1966; no letters to Corso are known at present.

April 1959 Answered query from English poet Elaine Feinstein; this letter was published with "Projective Verse" by LeRoi Jones. An addendum was written, although it may not have been sent; see letter 85 . Columbia also has eleven letters to Gael Turnbull, the Scottish 
poet and editor of Migrant, from about this time; see letter 84 .

November 1959 Received visits in Gloucester from Michael McClure (see letter 88), Philip Whalen (see letter 82, from the collection at Reed College), and LeRoi Jones, a very close associate until 1965 (see letter 104).

May 1960 Included in New American Poetry (ed. Donald Allen). The Maximus Poems (the Jargon-Corinth edition) was in preparation; see letter 84 .

September 1960 Gave a reading at Hammond's Castle, Gloucester. A local artist, Harry Martin, was present; see letter 111, from the six letters at Storrs.

December Joined in psilocybin experiments with Timothy

1960 - Leary; see letter 101. The Distances published by Grove February 1961 Press.

February 1962 Gave a reading at Harvard University; see letter 95, to Harry Levin.

December 1962 Sent first letter to Gloucester Daily Times; see letters 120 and 151. Olson's seventeen letters to the editor of the local newspaper are collected in Maximus to Gloucester.

July- Taught summer school at the University of British August 1963 Columbia, Vancouver, along with Creeley, Ginsberg, Duncan, Whalen, Denise Levertov, and Margaret Avison; no letters to the latter two exist; see letter 98, to Vancouver poet George Bowering.

September 1963 Joined the English department of the State University of New York at Buffalo; see letter 119, to the chairman Albert Cook, letter 105, to Mac Hammond, and letter 103, to Ralph Maud. Olson organized summer teaching for LeRoi Jones, Edward Dorn, and Robert Kelly (see letter 100). He wrote a review of Eric Havelock's Preface to Plato for Niagara Frontier Review, no. 1; see letter 102, to Havelock, and letter 110, to Harvey Brown.

March 1964 Betty Olson died in an automobile accident near their residence in Wyoming, New York; see letter 107, to Robert Creeley and Vincent Ferrini. 


\section{Chronology : xxxvii}

April 1965 John Wieners and Ed Sanders gave a reading in Buffalo. Letter 129, to Sanders, is one of two at Stony Brook; nineteen exist at Simon Fraser.

June-July 1965 Traveled to Italy for the Festival of Two Worlds, Spoleto, where he met the guest of honor, Ezra Pound. Thence to Bled, Yugoslavia, for a P.E.N. conference. Olson returned to the United States via Rome; see letter 113, to Mary Shore and Vincent Ferrini.

July- Traveled to California for the Berkeley Poetry August 1965 Conference; here he met Suzanne Mowat (see letter 114, from the collection of seventeen deposited at Storrs). Olson's recorded lecture was transcribed and published as Causal Mythology in 1969, and the evening reading as Reading at Berkeley; see letter 139. Human Universe and Other Essays was published in San Francisco by Auerhahn Press (it was published later in paperback by Grove Press).

September 1965 Returned to Buffalo, but was back in Gloucester within two weeks. Olson left John Clarke in charge of his seminars; see letter 116. Students who kept in touch included Albert Glover (see letters 115 and 116), Andrew Crozier (see letter 118), George Butterick (see letter 152), and Robert Hogg (see letter 127).

March 1966 Film crew from National Education Television shot a segment of "Poetry: U.S.A." in Gloucester for broadcast 4 September 1966.

August 1966 The small, beautiful volume 'West' arrived in Gloucester from the editor of Goliard Press, the poet Tom Raworth; see letter 132.

October 1966 Left for Liverpool and London with Panna Grady; see letter 141.

December 1966 Traveled to Berlin for a reading organized by Olson's German translator, Klaus Reichert (letters not available).

February- Call Me Ishmael was reissued by City Lights; see letter March 1967 124, to Lawrence Ferlinghetti. Selected Writings was edited by Creeley and published by New Directions; 
see letter 147 , to Donald Sutherland. Olson visited Jeremy Prynne (see letter 130; the mass of this correspondence is in possession of the recipient) and Edward Dorn, visiting lecturer at the University of Essex (see letter 131, from the collection of over one hundred deposited at Storrs). He also made a fiveweek trip to Dorchester, Dorset, for research on the Maximus series.

June-July 1967 Flew back to the United States and went on to Oxford, Ohio, to see Joyce Benson; see letter 134, from some twenty-seven deposited at Storrs. He returned to London for the International Poetry Festival on 12 July.

October 1967 Gave a reading at Cortland, New York; see letter 146, to Harvey Brown.

December 1967 Entrusted to Cape Goliard in England the publishing of Maximus IV, V, VI; see letter 154, to Barry Hall.

January 1968 Visited by George Butterick in Gloucester researching his Guide to the Maximus Poems (University of California Press, 1978). Olson was working on "A Plan for the Curriculum of the Soul," which was published by Butterick in Magazine for Further Studies, no. 5 (Buffalo, July 1968); see letter 152.

March 1968 Visited Beloit College, Wisconsin, to present a series of lectures; see letter 145, to Beloit professor Chad Walsh. Olson's lectures were edited posthumously as Poetry and Truth.

April 1968 Last visit to West Coast; returned via Tucson as a guest of Drummond Hadley (no letters are available at present).

June 1968 Hospitalized for two weeks. Ann Charters visited Gloucester for her book Olson/Melville: A Study in Affinity (1968), in which she quotes some letters.

July 1968 - Spent his last months in Gloucester. Olson had many August 1969 visitors during this period. During 1968 they included Alasdair Clayre from the BBC on 27 July; Inga Lovén from Sweden in mid August (see letter 171); and Jack Kerouac on about 17 August (no letters). Visitors in 


\section{Chronology : $x x x i x$}

1969 included Barry Miles in late January, who recorded a tape for Apple Records, London, that was eventually released as a Folkways LP (see letter 160); an M.A. student, Andrew S. Leinoff in early April (interview was transcribed in Olson, no. 8 [fall 1977], pp. 66-107); Gerard Malanga for a Paris Review interview on 15 April (transcription in Muthologos); Elsa Dorfman, to take photographs, on 25 May; Ralph Maud on 6 June; Edward and Jenny Dorn in mid August; and Charles Stein in late August.

Gloucester companions of these months included Gerrit Lansing (no letters are available at present), Joseph Garland (see letter 156), Thorpe Feidt (see letter 153), Vincent Ferrini (see letter 165), Peter Anastas (see letter 169), and Harvey Brown, who had taken up residence at nearby West Newbury (see letter 170).

September 1969 Arranged to meet Charles Boer in Cambridge and was driven down to Connecticut. Letters to Boer are quoted in his Charles Olson in Connecticut (1975).

October- Taught a graduate seminar for eight weeks at the November 1969 University of Connecticut at Storrs. He was admitted to a local hospital on 1 December. See letter 172.

January 1970 Died in a New York City hospital on 10 January from cancer of the liver. Buried in the cemetery in Gloucester after a memorial service on 13 January. 
This page intentionally left blank 